\title{
Gender in Dictionary Definitions: A Comparison of Five Learner's Dictionaries and Their Different Editions
}

\author{
Juhani Norri
}

Faculty of Information Technology and Communication Sciences, Tampere University, Finland

Correspondence: Juhani Norri, Faculty of Information Technology and Communication Sciences, Pinni B4064, FIN-33014 Tampere University, Finland

juhani.norri@staff.uta.fi 


\title{
Gender in Dictionary Definitions: A Comparison of Five Learner's Dictionaries and Their Different Editions
}

\author{
Issues of gender present an increasing challenge to lexicographers. The example \\ sentences cited in some dictionaries have been criticized for enhancing \\ stereotyped images of men and women. Definitions should similarly be free from \\ any gender bias, a requirement that may at times clash with the actual use of the \\ word in corpora. The present study focusses on the definitions of twenty-five \\ words in the twentieth and twenty-first-century editions of five learner's \\ dictionaries. The results show that there is a great deal of variation between the \\ works examined when it comes to associating individual words with men or \\ women. Furthermore, the different editions of a dictionary often manifest \\ vacillation in gender descriptions.
}

Keywords: gender, vocabulary, lexicography, definition, learner’s dictionary.

\section{Introduction}

The first dictionary aimed at foreign learners of English, West and Endicott's The New Method English Dictionary, was published in 1935. Seven years later, Hornby’s Idiomatic and Syntactic English Dictionary appeared, the precursor of what is today known as Oxford Advanced Learner's Dictionary, now in its ninth edition. The authors of these books were British, and for almost the entire twentieth century, this area of lexicography was in the hands of publishers located in Britain. It is not until the late 1990s that learner's dictionaries edited by American lexicographers enter the market. ${ }^{1}$

\footnotetext{
${ }^{1}$ For the history of English learner’s dictionaries, see Béjoint, 163-200; Cowie, English Dictionaries; Jackson, 129-32; Landau, Dictionaries, 74-77; and Yamada.
} 
The design of a dictionary depends crucially on its target audience. If the circumstances in which the word can be used are restricted, it is essential that those with a limited knowledge of the language be informed about this. In works aimed at learners of English, formal style, for example, is more often marked with the label formal than in general-purpose dictionaries, and accurate information about currency, often conveyed by descriptions such as dated or old-fashioned, is essential. ${ }^{2}$ It has also been discovered that dictionaries compiled for learners assign usage notes and labels to potentially insulting words with greater frequency than works aimed at a wider audience. ${ }^{3}$ Particular care is exercised in the drafting of definitions, which should be readily understandable and use words that advanced learners are expected to know already. In an attempt to ensure intelligibility, most learner's dictionaries employ what is called a defining vocabulary or controlled defining vocabulary, a selection of 2,000-3,000 highfrequency words used for writing the definitions. ${ }^{4}$ The so-called full-sentence definition is a style of defining developed in the context of learner's dictionaries, where it is now widely used. The meaning of the headword is explained with an entire sentence, as in the entry for sombrero in Collins COBUILD Advanced Learner's Dictionary: “A sombrero is a hat with a very wide brim which is worn especially in Mexico.”5

${ }^{2}$ Landau, Dictionaries, 218, 243.

${ }^{3}$ Norri, “Labelling,” 91.

${ }^{4}$ For a discussion of the pros and cons of controlled defining vocabularies, see Atkins and Rundell, 448-50; Béjoint, 171-3; Carter, 150-1; Cowie, English Dictionaries, 157-8; Svensén, 246-8; and Yamada, 201-2.

${ }^{5}$ Full-sentence definitions have been both applauded and criticized. See Atkins and Rundell, 441-3; Béjoint, 179-82; Cowie, English Dictionaries, 157-8; Svensén, 235-40; and Yamada, $202-4$. 
Dictionaries, like other literary products, have also been commented upon from the angle of gender. One such observation is that the compilers in general shy away from the label sexist, which appeared in the 1995 edition of the Oxford Advanced Learner's Dictionary, attached for example to chick and bird in the sense 'young woman'. ${ }^{6}$ In subsequent editions, the label was abandoned. The example sentences in the same dictionary were studied by Cowie, who in his comparison of the first (1948) and fourth (1989) editions noted an increased prominence of women in the examples and their portrayal in a wider range of professional roles, the result of a conscious effort on the part of the editorial team. ${ }^{7}$ Those developments were a response to writers like Whitcut, according to whom invented examples offer lexicographers the "greatest freedom to be non-sexist", ${ }^{8}$ and Gershuny, who had criticized the stereotyped contexts and the dominance of masculine nouns and pronouns in the illustrative sentences of the Random House Dictionary of the English Language. When the first edition of Collins COBUILD English Language Dictionary was published, it attracted criticism for the frequent appearance of women in example sentences relating to drug and alcohol abuse. ${ }^{9}$ The definitions of lexemes felt to be sensitive one way or another have also

${ }^{6}$ Norri, “Labelling,” 77, 88.

${ }^{7}$ Cowie, “Learner's Dictionary,” 286-8, 291-2. Herbst, 328, notes that the fifth edition of OALD has more female (59\%) than male (41\%) references in the example sentences from need to nervy. In his review of the BBI Combinatory Dictionary of English (1986), Gold gives the authors credit for avoiding the use of stereotypes in their examples, which present women as "inventors, gardeners, jurists, military officers, etc."

${ }^{8}$ Whitcut, 143.

${ }^{9}$ Kaye. For a study of gender in the example sentences of a children's dictionary, see Landau, "Expression of Changing Social Values.” 
given rise to comments. The eighth edition of Webster's New Collegiate Dictionary informed its users that the adjective effeminate meant "having feminine qualities (as weakness or softness) inappropriate to a man”, an infelicitous explanation later changed to "having feminine qualities untypical of a man”. Benson et al. cite the entry as an example of how "the treatment of sexist terms in dictionaries has shown improvement in recent years”. ${ }^{10}$

The present article is a survey of the treatment of gender in the definitions of five different British learner’s dictionaries, known as "the Big Five”. ${ }^{11}$ The drafting of definitions for a non-native speaker calls for particular care in avoiding any misinterpretable or biassed statements, including ones on the rather sensitive issue of gender. Another reason for focussing on learner's dictionaries is the importance generally attached to conveying cultural associations or connotations of lexemes in these kinds of works. ${ }^{12}$ The male or female aspect of a word in many cases seems to be part of the associative or connotative meaning rather than the core conceptual meaning. ${ }^{13}$ In future studies, it would be of interest to compare the results obtained in this survey with the treatment of the example words in general-purpose dictionaries.

All the editions of the Big Five published in the course of the twentieth and twenty-first centuries were included in the study. One of the main aims was to examine

\footnotetext{
${ }^{10}$ Benson et al., 223. According to Brewer, 21, the entry for master in the third edition of The Oxford English Dictionary illustrates the eradication of earlier sexist definitions.

${ }^{11}$ Béjoint, 164.

${ }^{12}$ Atkins and Rundell, 426-7; Ayto, 98; Jackson, 139-40.

${ }^{13}$ Commenting on the word sombrero, an anonymous reviewer observes that "[a] sombrero is just an object, and a sombrero will remain a sombrero if worn by a woman”.
} 
possible changes in gender indications from the first edition of the dictionary to the present day. Editors and compilers have changed in the course of the decades, as has the society around them. Our awareness of gender issues has increased. To what extent is all this reflected in the entries for the words studied? Where gender descriptions have been modified, it is of interest to examine whether the new formulations proved to be temporary or of a more longlasting nature. In the course of the study, each of the example words was looked up in the different editions of the dictionaries, and the gender information provided, if any, was noted down. The data collected also enabled a comparison of the policies adopted by the five dictionaries, including the question of whether we can detect any parallel developments in their gender descriptions.

When it comes to writing definitions, the task of lexicographers is complicated by ongoing shifts in the meanings of words. Semantic changes may be engineered, ${ }^{14}$ based on a decision made by the discourse community, but more often they are cases of the language evolving, sometimes rather subtly, without any conscious intervention from speakers. The availability of vast corpora, with material drawn from a wide range of varieties of English, has made it easier to detect such changes in their initial stages. The origins of the new usages often lie in informal spoken language or the language of subcultures, increasingly better represented in corpora. For lexicographers drafting definitions, the work done by semanticists and other lexical scholars suggests the kinds of words that are liable to shifts in their gender association and which may therefore call for special attention. Semanticists have discovered that words from a particular semantic area often have a tendency to change their meanings in a similar fashion, ${ }^{15} \mathrm{a}$

\footnotetext{
${ }^{14}$ Term from Bauer, 145.

${ }^{15}$ Lehrer cites examples from the semantic fields of animals, gambling, and dimension.
} 
finding that also applies to gender-related lexemes, as will be seen in Section 2, which provides an outline of earlier research into the changing gender boundaries of words.

\section{Gender-Referential Shifts in English}

Gender-related changes in the meanings of words first gained wider attention in the context of discussions about language and sexism in the 1970s. It was then observed that when a word used of both sexes comes to be applied only to women, it often takes on a more pejorative meaning. Whore seems to have meant 'a male or female lover' in its early history, and bawd signified 'a go-between or panderer of either sex' before it came to be applied to a woman in charge of a brothel. ${ }^{16}$ After the narrowing down of the meaning of girl from 'a child of either sex' to 'a female child', the word also started to denote a prostitute or mistress, and something similar happened to wench. ${ }^{17}$ When an originally masculine term extends its scope to cover females, the process may similarly involve pejoration. In its earliest written occurrences in Middle English, harlot carries the sense of 'vagabond, beggar', the modern application to an unchaste woman or prostitute becoming dominant in the sixteenth century. ${ }^{18}$

Burridge reminds us that the derogation of women evident in semantic shifts is not a thing of the distant past, but an ongoing phenomenon. She cites several twentiethcentury examples, among them tramp 'male vagrant', which in the 1920s developed the further meaning of 'promiscuous woman', and slag, first 'piece of refuse', then 'cheat,

\footnotetext{
${ }^{16}$ Schulz, 69-70.

${ }^{17}$ Ibid., 68, 70.

${ }^{18}$ Rawson, 187.
} 
contemptible person', and, since the 1950s, 'promiscuous woman'. ${ }^{19}$ Another word mentioned by Burridge, bimbo, is assigned three senses in The Oxford English Dictionary: ‘a fellow, chap; usually contemptuous’ (dated 1919), ‘a woman; esp. a whore' (1929), and 'a young woman considered to be sexually attractive but of limited intelligence’ (1927). The last-mentioned is said to be "now the usual sense”. ${ }^{20}$

When the denotation of a lexeme is narrowed down to one of the sexes or extended to cover both, the process does not necessarily lead to semantic downgrading. The word may have been highly insulting to begin with. Burridge notes that the scope of the disapprobatory expressions whore, bitch and slut, traditionally applied to females and gay males, now includes males in general. ${ }^{21}$ Examples of such extended usages of derogatory epithets are found especially in the language of subcultures. ${ }^{22}$

Sometimes both the old and the new usages have a positive ring to them. Singular guy usually refers to a man, as does the plural guys when used of particular persons, unlike in e.g. "good guys and bad guys”. In direct address, however, guys or you guys can be said to all-male, all-female, and mixed groups. When used like that,

\footnotetext{
${ }^{19}$ Burridge, Blooming English, 60.

${ }^{20}$ For further examples of gender-referential shifts associated with semantic pejoration, see Hughes, 220-3.

${ }^{21}$ Burridge, Weeds in the Garden of Words, 75.

${ }^{22}$ The first sense listed for whore in Cassell's Dictionary of Slang (ed. Green) is “a general derog. term of address, irrespective of sex". Bitch, labelled UK/W[est].I[ndies]., is described as “a general derog. term for a man” under sense 7. Coleman, 58-59, notes that in student slang the originally female dog ‘unattractive person' and whipped 'dominated by a sexual partner’ occasionally refer to men as well.
} 
guys according to Lawson functions as "almost a suffix to you to suggest friendliness, cameraderie, informality”. ${ }^{23}$

You guys illustrates one of the four types that Waksler distinguishes in the neutralization of gender in English vocabulary in the 1990s. Waksler's categories comprise (a) [+male] words extended to women (e.g. mensch), (b) [+female] words extended to men (e.g. bitch), (c) lexemes filling a gap in a grammatical paradigm (a rare type exemplified by you guys filling the need for a specific second person plural pronoun), and (d) originally [+male] terms in pairs like actor/actress and comedian/comedienne becoming the general usage. Waksler observes that gender neutralization in vocabulary is paralleled by similar developments in other areas, such as perfumes, where quite a few of the fragrances are now unisex. As Waksler puts it, "[g]ender neutralization is the move of the times". ${ }^{24}$

The semantic extension of forms like actor or comedian is an example of the suppression of derivational suffixes now regarded as discriminatory by many. The specific marking of the female sex in pairs like actor/actress and poet/poetess is seen to imply that female is not the norm, but a deviation from the standard. ${ }^{25}$ The effect of the suffix has also been characterized as trivializing, making the female term linguistically dependent on the male. ${ }^{26}$ Bauer et al. observe that -ette may be the main gendermarking suffix in present-day English, many of the formations having clearly

\footnotetext{
${ }^{23}$ Lawson, 158.

${ }^{24}$ Waksler, 6.

${ }^{25}$ Miller and Swift, Words and Women, 159.

${ }^{26}$ Pauwels, 110.
} 
disparaging connotations. ${ }^{27}$ Miller and Swift criticize -ette in coinages like usherette, the form of the latter word implying that "an usherette is a frivolous little woman hired to replace a bona fide usher”. ${ }^{28}$ Eckert and McConnell-Ginet also comment on -ette, noting that it merges gender and the basic diminutive meaning for example in Raylettes, the background singers for Ray Charles. The name of the group suggests that they are “not only female but small and cute". ${ }^{29}$

All of the examples cited thus far have been common nouns signifying human beings. The obliteration of gender boundaries can also be detected in proper names. In Britain, an orthographic distinction used to be made between male Leslie and female Lesley. ${ }^{30}$ The former spelling has gradually been extended to girl's names as well. The entry for Leslie in the 1990 edition of Hanks and Hodges's Dictionary of First Names describes the name as “m[ale]., occasionally f[emale]., esp. in the U.S.”. In the 2006 second edition, the headword Leslie is followed by the male and female gender symbols, with no mention of the U.S. or frequency of the female usage.

\footnotetext{
${ }^{27}$ Bauer et al., 396. Hellinger and Pauwels, 663, state that feminine suffixes in English "have not been productive for a while”. Bauer et al., 230, have, however, found examples of recent formations in -ess and -ette in corpora, and characterize the two suffixes as having "modest productivity”.

${ }^{28}$ Miller and Swift, Words and Women, 159.

${ }^{29}$ Eckert and McConnell-Ginet, 86. Baron, 125, cites Blondettes, Barberettes, Rockettes, and Roxyettes as examples of names of all-female groups of singers or dancers.

${ }^{30}$ In her dictionary of first names, Withycombe states that “Leslie is now a common man’s name, but is sometimes also given to girls, when it is usually spelt Lesley”. For a further discussion of the spelling Leslie, see Norri, “Gender-Referential Shifts,” 275-6.
} 
In observations about gender-referential shifts in vocabulary, relatively little attention has been paid to inanimate objects. In 1970, Foster, citing the words suit, blouse, stole, pants ('underwear'), and knickers (a shortening of knickerbockers), commented that "[s]ome psychologist should really tell us what envies and unfulfilled longings cause women to steal the names of men’s clothes”. According to Foster, briefs, which started out as a female term and later became gender-neutral, manifests “a curious reversal of the usual tendency”. ${ }^{31}$ Dovey was interested in studying the adoption of clothing terminology from French to English and vice versa. His long list of names of garments contains many instances of shifting gender boundaries. Frock, for example, first meant 'monk's long gown', the most common meaning now being 'woman or girl's dress'. Petticoat originally denoted 'a petty (small) coat' that men wore under their doublets. ${ }^{32}$ That Foster's views about women "stealing” the names of male clothes only present one side of the coin is shown by Norri's study of "lexical gender-benders in underwear”. Many of the gender-neutral terms for underwear in fact originated in the female wardrobe. ${ }^{33}$

Norri has presented a classification of gender-related changes that accommodates words for both human beings and inanimate objects. The main criterion in the categorization is the completeness of the semantic shift. Five different stages can be distinguished in the history of a word whose gender boundaries are being challenged

\footnotetext{
${ }^{31}$ Foster, 142-3.

${ }^{32}$ Dovey, 171.

${ }^{33}$ Norri, "Lexical Gender-Benders," 84, notes that “[o]f the gender-benders discovered in the present article, seven (nine if we include combination(s) and French knickers) had their origins in the female wardrobe, only four in the male”.
} 
or reassessed: (a) sporadic occurrences of the extended gender association (e.g. bloomers, virago, vixen), (b) the extended gender association begins to spread (e.g. swimsuit, undies, long johns), (c) parity (e.g. blazer, jacket, balls 'courage’), (d) the more recent gender association prevails (e.g. bimbo, blouse, Hilary), and (e) the original gender association is totally forgotten (e.g. harlot, shrew, petticoat). ${ }^{34} \mathrm{~A}$ particular word, as noted by Norri, may not fit easily into one or other of the five categories, as informants tend to disagree in their assessments about gender. The usage of special groups, furthermore, may never spread to the community as a whole. ${ }^{35}$

The above-cited research has shown that shifts in the gender boundaries of words are a common type of semantic change. In studies looking into the presentation of gender in dictionary entries, the selection of example sentences has so far been in the focus of attention. ${ }^{36}$ It is the definitions, however, which explicitly capture or fail to capture the semantic extension or narrowing of the word. The present article is a contribution to the study of definitions in particular, with special emphasis on learner's dictionaries. Gender-related shifts in word meaning, as shown by the earlier studies mentioned above, have taken place in recent decades, often progressing in stages. It is therefore important to examine all the editions of a particular dictionary for forming an idea of how the different editors and compilers have reacted to instances of unstable

\footnotetext{
${ }^{34}$ Norri, “Gender-Referential Shifts.” Some of the example words may no longer represent the same stage of development as in 1998.

${ }^{35}$ Ibid., 286.

${ }^{36}$ In their articles about gender issues in dictionaries, journalists have similarly focussed on the choice of example sentences. For such articles, see e.g. Astle; Caplan-Bricker; Crum; England; Flood; and Kestler-d’Amours.
} 
gender reference. A comparison of the major titles in pedagogical lexicography is also essential, as the evidence available to each varies and there may be significant differences in editorial policies.

Earlier literature on gender issues in vocabulary has prompted the selection of the twenty-five words chosen for closer scrutiny in the present study. Some of the lexemes examined have been discussed in articles by Waksler (actor/actress, comedian/comedienne, hero/heroine) and Norri (swimsuit, drawers). More importantly, earlier work on gender has revealed entire areas of vocabulary where gender shifts have been particularly frequent, including terms for professions, personal characteristics, and clothing. Items from all three lexical fields are represented in the dictionary analysis that follows.

\section{Dictionaries Studied}

The selection of works analysed for the present article consists of five leading dictionaries meant for advanced learners of English. Now in its ninth edition, the

Oxford Advanced Learner's Dictionary of Current English (hereafter OALD) has the longest history, ranging from 1948 to the present day. OALD’s junior by thirty years, the Longman Dictionary of Contemporary English (LDOCE) was first published in 1978 and has so far run to six editions. The Collins COBUILD Advanced Learner's Dictionary (Cobuild) has, like OALD, seen nine editions, the first one coming out in 1987. Towards the end of the twentieth century and at the beginning of the twenty-first, two more works aimed at learners of English entered the market. The Cambridge Advanced Learner's Dictionary (CALD) widened the selection in 1995 and the 
Macmillan English Dictionary for Advanced Learners (MEDAL) in 2002. Of the former, four editions have been published, of the latter, two.

In addition to the printed books, all five dictionaries are available digitally. In fact, the publisher of MEDAL announced in 2012 that they would no longer publish print editions of the dictionary, focussing instead on the online medium. ${ }^{37}$ The words examined were looked up in both the printed editions and the digital versions of each work. $^{38}$

Each of the five dictionaries make use of a defining vocabulary, the size of which ranges from 2,000 to 3,000 words. ${ }^{39}$ Another similarity is the heavy reliance of all five on electronic corpora. In its blurb, $O A L D$ mentions that the dictionary is based on the authoritative Oxford English Corpus. The Oxford Dictionaries website describes the corpus as containing over 2.5 billion words and representing "all types of English, from literary novels and specialist journals to everyday newspapers and magazines, and even the language of blogs, emails, and Internet message boards". ${ }^{40}$ A pioneer in the use of corpora in dictionaries aimed at learners, Cobuild has its foundation in the Collins Corpus, over 4.5 billion words collected from books, newspapers, magazines, websites, radio, television, and everyday conversation. ${ }^{41} \mathrm{LDOCE}$ takes thousands of its examples

\footnotetext{
${ }^{37}$ Rundell, "Stop the Presses."

${ }^{38}$ See the References for bibliographical details.

${ }^{39}$ For a comparison and critical assessment of the defining vocabularies in $O A L D$, Cobuild, LDOCE, and the Cambridge International Dictionary of English, see Bogaards, 289-91, and Herbst, 324-5.

${ }^{40}$ https://en.oxforddictionaries.com/explore/what-is-a-corpus (accessed September 6, 2018).

${ }^{41}$ Cobuild, 9th ed., v.
} 
from the Longman Corpus Network and the Longman Web Corpus. The former comprises some 390 million words of written and spoken British and American English from a variety of sources, including books, newspapers, conversations, and advertisements. ${ }^{42}$ The main source of language data for $C A L D$ is the Cambridge International Corpus, a collection totalling more than 1.5 billion words of spoken and written language "from a huge variety of sources". ${ }^{43}$ The definitions in $M E D A L$ are said to be based on the 200 million-word World English Corpus, which consists of the Bloomsbury Corpus of World English supplemented with additional material such as language teaching and learner texts. ${ }^{44}$

\section{References to Gender in the Dictionary Definitions}

For the examination of gender descriptions in learner's dictionaries, twenty-five words were chosen for closer scrutiny. The analysis focusses on items from three different semantic fields, which are professions and occupations (e.g. actor, midwife, starlet), personal characteristics and roles (e.g. bastard, redhead, sissy), and clothes (e.g. fez, sombrero, swimsuit).

\subsection{Words for Professions and Occupations}

\footnotetext{
${ }^{42}$ LDOCE, 6th ed., xii.

${ }^{43} C A L D$, 4th ed., ix.

${ }^{44} M E D A L, 2 d$ ed., ii.
} 
The nine words in this group are actor, boxer, comedian, midwife, nurse, priest, soldier, starlet, and stripper. The level of agreement between the five dictionaries is higher for some of the items than for others. There is almost complete harmony in the descriptions of boxer, comedian, nurse, and soldier, generally unspecified as to the sex of the person designated. To cite some formulations of the gender-neutral type, we find "a person who boxes, especially as a job” for boxer in $O A L D$ (6th-9th eds. 2000-15), “someone whose job is to entertain people by telling jokes and stories to make them laugh” for comedian in MEDAL, "a person whose job is to care for people who are ill or injured, especially in a hospital” for nurse in $C A L D$, and “[a] soldier is a person who works in an army, especially a person who is not an officer” for soldier in Cobuild. ${ }^{45}$ The only hint at boxers being men occurs in the first (1987) edition of Cobuild, where the word is said to mean "a sportsman whose sport is boxing", subsequently changed to "[a] boxer is someone who takes part in the sport of boxing”. In the same volume, comedian is defined as “a person, usually a man, whose job is to make people laugh, especially by telling them jokes or funny stories”. The phrasing used from the second (1995) edition onwards, “[a] comedian is an entertainer whose job is to make people laugh, by telling jokes or funny stories”, brought Cobuild into line with the other dictionaries examined. The placing of the notes “(fem comedienne)” in OALD (4th \& 5th eds. 1989 \& 1995) and “(comedienne fem)” in LDOCE (2d ed. 1987) right after the headword, before a gender-neutral definition, is a source of potential confusion. Are we supposed to deduce that when talking about a woman, only the form comedienne can be used? A comparison of the fourth and fifth editions of $O A L D$ shows that the lexicographers drafting the entries for comedian were faced with complexities of gender:

\footnotetext{
${ }^{45}$ When no edition is specified, the definition is identical in all the editions of the dictionary.
} 
(1) (fem comedienne) (a) entertainer who tells jokes, performs sketches (SKETCH 3), etc to amuse an audience (b) actor or actress who plays comic parts (4th ed. 1989)

(2) (fem comedienne) (a) an entertainer on stage, television, etc who makes people laugh by telling jokes, etc (b) an actor who plays comic parts (5th ed. 1995)

It was probably in the interests of clarity that both $O A L D$ and $L D O C E$ soon returned to their earlier practice of assigning separate entries to comedian and comedienne. In its treatment of the two words, $C A L D$ has resorted to the adverb also, which makes it clear that the form comedian can be used of both sexes:

(3) (female also comedienne) a person whose job is to make people laugh by telling jokes and funny stories or by copying the behaviour or speech of famous people (4th ed. 2013)

Observations about gender occur only rarely in the entries for nurse, but the first two (1978 \& 1987) editions of $L D O C E$ and the fourth (1989) edition of $O A L D$ are an exception. Both men and women may find reasons for disgruntlement in the LDOCE description of a nurse as "a person, typically a woman, who is trained to take care of sick, hurt, or old people, esp. as directed by a doctor in a hospital”. The mention of women in particular has since been deleted, and there is no longer any implication of a hierarchical relationship between doctors and nurses. Dealing with the same word, 
OALD manifests a curious and, it would appear, inexplicable "U turn” in its gender statements, revealed through a comparison of the third, fourth, and fifth editions:

(4) person, usu trained, who cares for people who are ill or injured (3d ed. 1974)

(5) person, usu female, trained to help a doctor to look after the sick or injured (4th ed. 1989)

(6) a person trained to help a doctor to look after sick or injured people (5th ed. 1995)

The part about helping a doctor is omitted in later editions.

As regards gender comments in the entries for soldier, two volumes differ from the rest. The first (1978) edition of $L D O C E$ tells the reader that a soldier is "a member of an army, esp. a man and esp. one of low rank (not an officer)”, a description first changed to "someone who serves in the military forces of a country; a member of an army, esp. one who is not an officer" (2d ed. 1987), then shortened to "a member of the army of a country, especially someone who is not an officer” (3d-6th eds. 1995-2014). Again, $O A L D$ first adds a gender specification, then removes it:

(7) member of an army, one who is not a commissioned or non-commissioned officer (3d ed. 1974)

(8) member (usu male) of an army, esp one who is not an officer (4th ed. 1989)

(9) a member of an army, esp one who is not an officer (5th-9th eds. 1995-2015) 
One of the words studied, starlet, is systematically associated with women, the word actress appearing in many of the definitions. Why the fifth (1995) edition of $O A L D$ chose to include the adverb especially in its entry remains a mystery, but the modification was short-lived:

(10) (sometimes derog) a young actor, esp a woman, who hopes to become a film star but is not yet very famous (5th ed. 1995)

(11) a young woman actor who plays small parts and hopes to become famous (6th9th eds. 2000-15)

The remaining four terms for professions and occupations exhibit greater variation in gender descriptions. The trend to call women acting in plays or films actors rather than actresses was observed in the early 1980s already. ${ }^{46}$ In Nunberg's study, however, the majority of the 175-member Usage Panel of The American Heritage Dictionary found actress acceptable in 1988, but the results varied according to the sentence containing the word. Nunberg concluded that "the distinction between actor and actress is allowed, since that is one profession in which the jobs one can take obviously depend on one’s sex”. ${ }^{47}$ Burchfield, in 1996, listed actress among central -ess words "remaining in use more or less unchallenged", ${ }^{48}$

\footnotetext{
${ }^{46}$ Beardsley, 159.

${ }^{47}$ Nunberg, 478.

${ }^{48}$ Burchfield, 263.
} 
Of the five learner's dictionaries, Cobuild systematically associates actor with men, but not without qualification. In the first (1987) edition, it is stated that ““'[a]ctor” in the singular usually refers to a man”, which was later expanded with the clause "but some women who act prefer to be called 'actors' rather than 'actresses'” (2d-9th eds. 1995-2018). Three editions of OALD and LDOCE that were published before Cobuild entered the market illustrate the old, stricter division of labour between actor and actress, seen from the following entries for actor:

(12) man who acts on the stage or for cinema films (OALD, 2d ed. 1963)

(13) a man who acts on the stage, TV or in films (OALD, 3d ed. 1974)

(14) a man who takes part in a play (LDOCE, 1st ed. 1978)

As with nurse and soldier, OALD shows a return to the older version in the course of its history: the first (1948) edition uses the gender-neutral person in its description of actor, as do all the editions from the fourth (1989) onwards. When it first came out in 1995, CALD apparently also had doubts about the applicability of the word actor to a woman. The sentential definition of actor states that "[a]n actor or actress is someone who pretends to be someone else while performing in a film, theatrical performance, or television or radio programme”. The formulation in subsequent editions (2005-13) is unambiguous, with the note “(female also actress)” prefixed to a definition beginning with "someone who pretends to be someone else..." (cf. (3) above). All in all, MEDAL and the later editions of $O A L D, L D O C E$, and CALD do not assign the form actor to the male sex, either exclusively or especially.

The increased sensitivity in the application of terms relating to professions and occupations can also be detected in the entries for midwife. The most recent addition to 
British learner's dictionaries, $M E D A L$, does not include any gender specification, while all the others do, at least at some point during their history. The earliest editions of OALD state that a midwife is a woman, but from the fourth (1989) edition onwards the phrasing is changed to “a person, especially a woman...”, an assessment similar to CALD’s “a person, usually a woman...”. Cobuild initially took a similar line, informing the reader that "[a] midwife is a nurse, usually a woman, who is trained to deliver babies and to advise pregnant women”, but the gender-related comment was abandoned in the second (1995) edition and has not returned since. The dictionary with the most varied record is $L D O C E$ with its three different types of information, progressing chronologically from most gender-specific to neutral:

(15) A woman, usu. a nurse, who has received a special training to help other women when they are giving birth to children (1st ed. 1978)

(16) a person, usu. a woman, who is not a doctor but helps women when they are giving birth to children (2d ed. 1987)

(17) a specially trained nurse whose job is to help women when they are having a baby (3d ed. 1995)

The analysis of priest yields a profile that closely resembles that of midwife when it comes to mentioning gender in the various dictionaries or editions. MEDAL, again, mentions neither sex in its definition "someone whose job is to lead worship and perform other duties and ceremonies in some Christian churches”. CALD, as in its entries for midwife, invariably resorts to the adverb usually: "a person, usually a man, who has been trained to perform religious duties in the Christian Church, especially the 
Roman Catholic Church.” The first (1987) edition of Cobuild differs from the rest of the volumes in the series, a situation familiar from the above discussion of midwife:

(18) A priest is a man who is a member of the Christian clergy, especially in the Catholic, Anglican, or Orthodox church. (1st ed. 1987)

(19) A priest is a member of the Christian clergy in the Catholic, Anglican, or Orthodox church. (2d-9th eds. 1995-2018)

The earlier editions of $L D O C E$ similarly differ from the later ones, stating that a priest is “esp. a man” (1st ed. 1978) or “usu. a man” (2d ed. 1987). After that, the gender indication disappears, reminiscent of the history of midwife in the same dictionary. As regards $O A L D$, the use of the word clergyman as a central element in the first and second (1948 \& 1963) editions points to a male referent. The later rewritten definitions mention neither sex, but there are additional notes in the third and fourth (1974 \& 1989) editions stating that clergyman is the usual term in the Anglican Church. Except in the case of $C A L D$, the general picture for priest is an obliteration of gender boundaries, a development reflecting reforms in the church over the last two decades or so.

The last word in the present semantic group, stripper, attracts mentions of gender in three dictionaries, the most straightforward description occurring in the first (1987) edition of Cobuild. Examples (20)-(21) show how the word woman was later changed to person, possibly to reflect actual changes in this branch of the entertainment industry, but more likely in an attempt to avoid a view of the occupation that could be regarded as sexist. 
(20) A stripper is a woman who earns money doing striptease in clubs or at parties. (1st ed. 1987)

(21) A stripper is a person who earns money by doing striptease. (2d ed. 1995)

In the third (1974) edition of $O A L D$ and first and second editions (1978 \& 1987) of LDOCE, stripper is associated with women indirectly, through other words in the dictionary. OALD defines stripper by referring to stripshow, a "dance, cabaret or theatrical entertainment in which a person (usu a woman) takes off garments one by one”. LDOCE provides a cross-reference to striptease, said to be “(a) removal of clothes by a person, esp. a woman, performed as a show” (1st ed. 1978) or “a performance, esp. by a woman, in which the performer takes off her or his clothes in a sexually exciting way” (2d ed. 1987). In the latter definition, the phrase her or his catches the eye, being another indication of female prevalence. The same co-ordinated possessive also appears in the fifth (1995) edition of $O A L D$, to be reversed in the sixth (2000), most likely in an attempt to avoid sexist overtones by using the more common order of the two parts:

(22) a performer who removes her or his clothes in front of an audience as a form of entertainment (5th ed. 1995)

(23) a performer who takes his or her clothes off in a sexually exciting way in front of an audience (6th-9th eds. 2000-15)

It is noteworthy that the observations about stripper being a female term occur in the earlier editions of the dictionaries. 


\subsection{Words for Personal Characteristics and Roles}

In this semantic group, the focus lies on exploring the dictionary treatment of adventurer, bastard, brute, divorcee, hero, looker, lover, redhead, sex object, and sissy. With some of the words, there is near-uniformity as regards the gender descriptions provided. The entries for adventurer, for example, generally lack any reference to men or women, except for the first (1987) edition of Cobuild:

(24) An adventurer is $\mathbf{1}$ a person, especially a man, who tries to become rich or powerful by using dishonest or immoral methods; used showing disapproval. 2 a person who enjoys adventure.

The order of the two senses was later reversed, with a concomitant revision of the phrasing:

(25) 1. An adventurer is a person who enjoys going to new, unusual, and exciting places. 2. If you describe someone as an adventurer, you disapprove of them because they are using dishonest or immoral methods to gain money or power. (2d \& 3d eds. 1995 \& 2001)

The fourth and subsequent editions (2003-18) list only the first sense in (25). OALD in its fourth and fifth editions (1989 \& 1995) annexed the note "(fem adventuress)” to the headword, before the two gender-neutral definitions. As with comedienne, it is not entirely clear whether the form in brackets was supposed to be the only one applied to 
women. The aim to clarify the issue is the likely reason for the dictionary's return in later editions to the practice of assigning separate entries to adventurer and adventuress. Sex object is another lexeme hardly ever accompanied by information about gender. Only two such notes appear in the thirty printed volumes and five online versions examined. The following passages come from the fifth (1995) edition of OALD and the first (1987) of Cobuild, respectively:

(26) a person, usu a woman, considered only in terms of her or his sexual attraction

(27) If someone, especially a woman, is considered as a sex object, they are considered only in terms of their physical attractiveness and not their character or abilities.

The ordering of the elements in the two-part possessive in $O A L D$, also found in the description of stripper in the same volume, further emphasizes the preponderance of women as sex objects. Both $O A L D$ and Cobuild soon rewrote their definitions so as to avoid any gender bias. The earlier versions were replaced with "a person considered only for their sexual attraction and not for their character or their intelligence” (OALD, 6th-9th eds. 2000-15) and "[i]f someone is described as a sex object, he or she is considered only in terms of their physical attractiveness and not their character or abilities” (Cobuild, 2nd-9th eds. 1995-2018).

Gender also receives scant attention in the entries for lover. Cobuild, CALD, and MEDAL say nothing about the matter. It is only the earliest editions of $O A L D$ and LDOCE that inform the reader that a lover is a man, a statement mostly qualified with the adverb chiefly, especially, or usually. The first edition (1978) of LDOCE states that a lover is "[a] man in love with or having a sexual relationship with a woman outside of 
marriage”, but in the next version love has fallen by the wayside and the gender assignment is less strict: "a person (usu. a man) who has a sexual relationship with another person outside marriage, esp. over a long period”. The history of the $O A L D$ definitions of lover manifests a diminishing role of love and widening of the gender reference, similar to the development in LDOCE. The five different descriptions found in $O A L D$ are all worth citing, as they illuminate not just the complexities of defining caused by semantic shifts, but also the difficulty of deciding whether gender is an essential item of information that should be included in the description:

(28) (chiefly a man) one who is in love; one who deeply admires a person of the opposite sex (1st ed. 1948)

(29) person, esp. a man, who deeply admires a woman; woman's sweetheart or suitor (2d ed. 1963)

(30) person in love with another; regular sex partner (3d ed. 1974)

(31) partner (usu a man) in a sexual relationship outside marriage (4th ed. 1989)

(32) a partner in a sexual relationship outside marriage (5th-9th eds. 1995-2015)

Our lexicographers agree in their gender assessment of two more words, brute and sissy. Brute is described as a male term, some entries including the qualifier usually (Cobuild, 2d-9th eds. 1995-2018) or especially (LDOCE, 1st \& 2d eds. 1978 \& 1987), but there is one notable exception. In the second to fifth (1963-95) editions of OALD, the original man has given way to person, to reappear in the last four editions (200015), where we learn that a brute is "a man who treats people in an unkind, cruel way". The reasons for the vacillation can only be conjectured. $O A L D$ has another unaccountable gap in the gender descriptions of sissy, the phrase "effeminate boy or 
man” (2d ed. 1963) first changing to "effeminate or cowardly person” (3d ed. 1974), then to "effeminate or cowardly boy or man" (4th ed. 1989). The lexicographers working for the first (1987) edition of Cobuild distinguished between male and female applications of sissy, but the use for women or girls must have been thought uncommon or exceptional, as it was omitted in the second (1995) edition, not to return:

(33) 1. A boy is described as a sissy, especially by other boys, if he does not like sport and is afraid to do things that are slightly dangerous. 2. A girl or young woman is described as a sissy, especially by other girls, if she is weak and cowardly. (1st ed. 1987)

(34) Some people, especially men, describe a boy as a sissy when they disapprove of them because they think he is not manly enough, for example that he does not like sport or is afraid to do things that are slightly dangerous. (2d ed. 1995)

The sequence of pronouns in (34) is something of a muddle, especially for foreign learners, which led to a further reformulation and the present version explaining that “[s]ome people, especially men, describe a boy as a sissy when they disapprove of him because he does not like rough, physical activities or is afraid to do things which might be dangerous”. The earlier “sport” has been replaced with “rough, physical activities”, probably to avoid suggesting that liking sport is a typically male trait. $O A L D$ certainly saw a connection between boys and certain characteristics in its fifth (1995) edition, where sissy is defined as "a boy who lacks the qualities thought to be typical of boys, eg courage and a sense of adventure”. In view of the present-day emphasis on gender equality and avoidance of stereotyped descriptions, many readers probably wondered why courage and a sense of adventure should be considered typical of boys in 
particular. ${ }^{49}$ Not surprisingly, the definition was rephrased for the sixth and subsequent (2000-15) editions: “a boy that other men or boys laugh at because they think he is weak or frightened, or only interested in the sort of things girls like”. The histories of the CALD and $L D O C E$ entries for sissy show that even a very general reference to qualities considered male, or, one would imagine, female, is now out of place:

(35) a boy who looks or behaves like a girl or who lacks qualities considered as male, or a person who is weak and cowardly $(C A L D, 1$ st ed. 1995)

(36) a boy who other boys dislike and laugh at because they think he is weak or interested in activities girls usually like, or a person who is weak and cowardly (CALD, 2d-4th eds. 2005-13)

(37) a boy who looks or acts like a girl in some way; one who lacks qualities believed to be typical of men or boys (LDOCE, 2d ed. 1987)

(38) a boy that other boys dislike because he prefers doing things that girls enjoy (LDOCE, 3d-6th eds. 1995-2014)

As appears from the above, CALD differs from the four other dictionaries examined in distinguishing two senses of sissy, one restricted to boys, the other applied to people in general. $M E D A L$ is the only recent work where men are included in the definition "a boy or man who does things that girls or women usually do”.

\footnotetext{
${ }^{49}$ Lederer criticizes the entry for manly in Webster's Third International Dictionary for citing boldness, resoluteness, openness in conduct, and courage as "qualities of a man”. In the same dictionary, Lederer notes, one of the example sentences for womanly suggests that volubility is typical of women in particular.
} 
There is more variation in the treatment of the remaining five words in this semantic category. Regarding the mention of men and women in the entries for divorcee, looker, and bastard, in each case one of the dictionaries stands out from the rest. Divorcee, for example, is “especially a woman” for Cobuild and $O A L D$, the current formulation in $O A L D$ succeeding the earlier “divorced person” (2d-4th eds. 1963-89). The first three (1995-2008) editions of CALD provide no gender information, but the fourth (2013) observes a difference between the uses of divorcee in Britain and America, a geographical distinction absent from the other dictionaries:

(39) 1 UK a man or a woman who is divorced and who has not married again. 2 (also divorcée) US a woman who is divorced and who has not married again.

$C A L D$ is the only work to treat divorcée as a variant of divorcee. OALD and Cobuild assign separate entries to the two forms, and, like $C A L D$, regard the accented version as American usage. MEDAL and LDOCE, perhaps a little surprisingly, do not list divorcee at all, only divorcée, for which MEDAL mentions no geographical restriction. Except for $L D O C E$, all the dictionaries state that divorcée refers to women. The entry for divorcée in LDOCE leads to confusion worse confounded as concerns both geography and semantics:

(40) 1 AmE old-fashioned a woman who is divorced $2 \mathrm{Br}$ a man or woman who is divorced

The analysis of looker yields more straightforward results. There is little chronological variation between the different editions of the five dictionaries. When the 
word first appears in $O A L D$, it is defined as “a good-looking person” (3d ed. 1974), followed by “attractive girl or woman” (4th ed. 1989), then "an attractive person, usually a woman” (5th-9th eds. 1995-2015). MEDAL manifests a similar development, from “a very attractive person” to “a very attractive person, usually a woman”. LDOCE and $C A L D$ have systematically associated the word with women, resorting, however, to the qualifying adverbs usually or especially in all the volumes. The one dictionary that stands out from the rest is Cobuild, whose definition suggests that neither sex is prominent as the referent of the word. The reader is informed that "[y]ou can refer to an attractive man or woman as a looker or a good looker” (2d-9th eds. 1995-2018).

For the present article, bastard was examined in the senses 'an unpleasant person' and 'a person of the stated kind'. The latter usage appears for example in the phrases lucky bastard and poor bastard. In Table 1, the more negative sense is presented first, separated from the lucky/poor bastard type by a slant.

Table 1 Gender specifications for bastard 'an unpleasant person' / 'a person of the stated kind'.

As can be seen from the table, the more recent editions treat the clearly disapprobatory bastard as a male appellation, a statement mostly qualified with “especially” or "usually”. CALD, however, is out of line, the expected gender indication in the earliest definition “an extremely unpleasant person, esp. a man” (1st ed. 1995) disappearing in the subsequent phrasing "an unpleasant person” (2d-4th eds. 2005-13). Cobuild manifests an inexplicable gap in the presentation of the milder usage from the fourth to the ninth (2003-18) editions, but the online version reproduces the exact words of the third (2001) printed edition: "Some people say things such as lucky 
bastard or poor bastard to refer to a person, usually a man, who they think is very lucky, or very unlucky”.

The changing gender descriptions from one edition to the next are well illustrated by the entries for bastard in $L D O C E$, where we also note an increasing amount of pragmatic information:

(41) 2 sl a man that one strongly dislikes 3 sl a man; fellow (1st ed. 1978)

(42) 2 sl an unpleasant, disagreeable, or cruel person 3 sl any person, esp. a man, of the stated kind (2d ed. 1987)

(43) 1 taboo a very offensive word for someone, especially a man, who you think is unpleasant. Do not use this word. 2 spoken informal not polite a man who you think is very lucky or very unlucky - often used humorously (3d ed. 1995)

For the remaining items in this semantic category, redhead and hero, three of the dictionaries provide similar gender descriptions, different from the other two. Cobuild, $C A L D$ and $M E D A L$ associate redhead especially with women, except for the first (1987) edition of Cobuild, where readers learn that "[a] redhead is a person whose hair is a colour between red and brown". The gender markings for $O A L D$ and $L D O C E$ resemble one another. There is one edition in the middle of each series where redhead is said to denote especially women. In all the other volumes, the definitions are of the type "someone who has red hair” or "person who has red hair”.

The data for hero is presented in Table 2. Hero, like bastard, is a polysemous word, here examined in the senses 'person famous for bravery' and 'main character in a story'. The bravery-related use is presented first, separated from heroes in books or plays by a slash. Generally speaking, the more recent editions of $O A L D$, Cobuild, and 
LDOCE are seen to form one group, as they state that a hero in the bravery sense is a man (LDOCE) or especially a man (OALD, Cobuild), while heroes in literary products are men (OALD, Cobuild), or men and boys (LDOCE). CALD and MEDAL paint a different picture, as gender information is provided only for a hero in a book or play, specified as male. The placing of the note "heroine fem" right after the headword, before the two definitions, in the second (1987) edition of LDOCE is reminiscent of the quandaries discussed earlier in connection with similar mentions of comedienne and adventuress. Again, the solution adopted in the later versions was to assign hero and heroine to separate entries. This has not happened in $C A L D$, where the second to fourth editions (2005-13) have the following entry for hero:

(44) [PERSON] > 1 (FEMALE heroine) a person who is admired for having done something very brave or having achieved something great 2 (FEMALE heroine) the main male character in a book or film who is usually good

As concerns the second sense, the prefixing of the phrase "(FEMALE heroine)" to a uniquely male definition is an infelicitous solution. It is, furthermore, not entirely clear whether the reader is supposed to deduce that only the form heroine can be applied to women in either sense. That was not the view expressed in the first (1995) edition of $C A L D$, where there was a similar note, identically placed, but with the text "female also heroine".

Table 2 Gender specifications for hero 'person famous for bravery' / 'main character in a story'. 


\subsection{Words for Clothes}

The six names of clothes studied for the present article are bathing costume, drawers, fez, sombrero, swimsuit, and top. It is again convenient to discuss cases of near harmony first. All five learner's dictionaries have provided gender-neutral descriptions of top for a couple of decades now. MEDAL, for example, writes that the word means "a piece of clothing that covers the upper part of your body”. When top as a clothing term first appeared in $O A L D$, Cobuild, and $C A L D$, however, it was associated with female apparel:

(45) (esp. woman's) garment covering the upper part of the body $(O A L D$, 4th ed. 1989)

(46) A top is a piece of clothing that a woman wears on the upper half of her body, for example a blouse. (Cobuild, 1st ed. 1987)

(47) A top is any piece of light clothing worn by women on the part of the body above the waist. (CALD, 1st ed. 1995)

Later entries for top contain no references to women in particular. The unisex nature of the word is further emphasized by the expanded selection of examples in Cobuild, where “for example a blouse” first becomes “for example a blouse or T-shirt” (2d ed. 1995), then the current "for example a blouse or shirt" (3d-9th eds. 2001-18). It is possible that top started off as a primarily female term, but has shifted its meaning to include both sexes. The need to have a word for the upper part of the male as well as female apparel is evident in fashion catalogues, where both “women's tops” and "men’s tops” are standard phrases nowadays.

Three of the dictionaries (OALD, CALD, MEDAL) do not restrict the word drawers to either sex. Drawers last appears in the printed volumes of Cobuild in the 
third (2001) edition, which states that “[d]rawers are underpants, especially ones worn by women”. The word, labelled old-fashioned, disappears after that, but emerges in the online version, briefly defined as "the same as underpants" and characterized as mainly US, old-fashioned. The reference to underpants causes uncertainty, as the definition for the latter word informs us that "i[n] British English, underpants refers only to men’s underwear, but in American English it refers to both men's and women's”. It is unclear whether the British and American gender distinction should also be taken to hold for drawers. As regards British English, that would misrepresent the actual situation. LDOCE is systematic in its description of drawers as underwear for women, or women and girls.

The two names for headgear, sombrero and fez, perhaps somewhat surprisingly, lack any gender comment in Cobuild, except for sombrero in the first (1987) edition: “A sombrero is a man's hat with a very wide brim which is worn especially in Mexico". “Man's hat” later becomes just "hat”. The entries for fez in LDOCE show a similar eradication of male wearer, as the original "[a] kind of round red hat with a flat top and no BRIM, worn by some Muslim men” (1st ed. 1978) is cut down to "a round red hat with a flat top and no BRIM” (3d-6th eds. 1995-2014). The more recent editions of $O A L D$ agree that it is men who wear a fez or a sombrero, but the gender information has also been at times suppressed during the long history of the dictionary, for no obvious reason:

(48) red felt hat with a flat top and a tassel but no brim, worn by men in certain Muslim countries (fez, 4th ed. 1989)

(49) a red hat with a flat top and a TASSEL, but no BRIM (5th ed. 1995) 
(50) broad-rimmed hat (as worn in Latin American countries) (sombrero, 2d \& 3d eds. $1963 \& 1974)$

(51) man's felt or straw hat with a very wide brim (as worn in Latin American countries, esp. Mexico) (4th ed. 1989)

Some of the dictionaries have kept their gender assignments of fez and sombrero constant throughout their history. Both hats are said to be worn by men in the two editions and online version of MEDAL. CALD first explains what a fez looks like and then adds the comment "especially as worn in the past by men in some Muslim countries”. The qualifier especially is also a regular part of the definitions of sombrero in $C A L D$, said to be “worn especially by men in Mexico”. One wonders whether the word order "worn by men especially in Mexico" would have resulted in a more accurate description. LDOCE systematically calls a sombrero "a man's hat” or "a hat for men”.

The analysis of the gender descriptions of swimsuit and bathing costume is complicated by the large number of cross-references used instead of definitions. The eighth (2010) edition of $O A L D$, for example, refers a reader looking up bathing costume to the entry for swimming costume. Under the latter word, yet another cross-reference is supplied, this time to swimsuit. An unrelenting user of the dictionary following that signpost finally reaches a proper definition, “a piece of clothing worn for swimming, especially the type worn by women and girls”. The frequent use of cross-references in $O A L D$ has been characterized as "a space-saving device which will not always be welcomed by those who are trying to understand the text they are reading”. ${ }^{50}$

\footnotetext{
${ }^{50}$ Bogaards, 292.
} 
The gender profiles for swimsuit and bathing costume are very similar in the dictionaries studied. In fact, Cobuild has, since the second (1995) edition, had an identical definition for both words, "a piece of clothing that is worn for swimming, especially by women and girls”. In the first (1987) edition, the description of bathing costume was different, “a tight-fitting garment covering a person’s trunk, which women wear when they go bathing”. In its treatment of both words, $O A L D$ at first omitted any mention of gender, the third (1974) edition, for example, defining both bathing costume and swimsuit as "garment worn for swimming”. In the more recent editions, the two terms are associated with especially women and girls, as in Cobuild. MEDAL, which lists only swimsuit, is a third dictionary that mentions female swimwear in particular: "a piece of clothing worn for swimming, especially by women”. The remaining two dictionaries, $L D O C E$ and $C A L D$, manifest an opposite development, as the originally female component of meaning disappears from the later versions. The last four (19952014) editions of $L D O C E$ assign no gender specification to bathing costume or swimsuit, contrary to the first two editions (1978 \& 1987), where both words are said to denote a garment “worn by women”. Similarly, CALD's current “a piece of clothing that you wear for swimming” (2d-4th eds. 2005-13) for both bathing costume and swimsuit was preceded by "a piece of clothing, or sometimes two pieces of clothing, which is worn by women for swimming”.

Fashion terminology provides plenty of examples of gender-referential shifts. Based on the occurrences of the word in newspaper corpora, Norri placed swimsuit among the cases where "the extended gender association begins to spread", ${ }^{51}$ which suggests that the history of the definitions in $L D O C E$ and $C A L D$ may reflect changes in

\footnotetext{
${ }^{51}$ Norri, “Gender-Referential Shifts,” 276-7.
} 
the actual use of the word. Swimsuit, like top, is indeed a likely candidate for extension of gender boundary, because the basic meaning, 'a garment for swimming', applies to men as well as women. In some other instances, changes in fashion such as unisex underwear may have been a major factor behind the semantic development. Unisex underwear has been on the market since the 1980s: ${ }^{52}$

(52) Les Girls Les Boys Is The Unisex Underwear Brand You Need On Your Radar ${ }^{53}$

(53) The trend in unisex underwear was further crystallised in the spring, when Calvin Klein reissued its original pants from the early 90s [...] Famously unisex-friendly Swedish brand Acne recently launched a line of "genderneutral” underwear. ${ }^{54}$

\section{Concluding Remarks}

The analysis of the five learner's dictionaries has shown that certain areas of vocabulary manifest clearer tendencies than others when it comes to indications of gender. Generally speaking, the dictionaries studied follow a similar trend in their entries for professions and occupations, where, except for starlet, the lexemes have been losing their gender attributions. The overall picture for the words denoting personal characteristics and roles is different, as no clear tendency

\footnotetext{
${ }^{52}$ Snodgrass, 341.

${ }^{53}$ Sciarretto.

${ }^{54}$ Ferrier.
} 
towards gender-neutral descriptions is discernible. While adventurer, lover, and sex object, for example, have lost what male or female specifications there were at one time, divorcee and looker are now more often associated with women than they used to be. The six names for clothes studied have been losing rather than gaining gender assignments.

A closer analysis of the definitions of the twenty-five words shows that issues of gender have been something of a challenge for lexicographers. In the chronologically arranged tables for bastard and hero, the five learner's dictionaries often differ from each other in the gender descriptions recorded for particular years. Examination of the various editions of each dictionary has revealed "U turns" where an earlier gender attribution was deleted only to make its return later on. Sometimes an edition stands out from the preceding and following ones by its unique reference to one of the sexes. The "U turn” type of changes, coupled with more straightforward additions or deletions of information relating to the sex of the referent, illustrate the truly chequered history of gender indications in learner's dictionaries. There has been further vacillation in the use of notes like "fem comedienne”, “fem adventuress", and “fem heroine”, placed immediately after the respective headwords comedian, adventurer, and hero. The interpretation of such phrases is not evident. They have usually been deleted from the more recent editions and forms like comedian and comedienne are listed as separate headwords.

There are several possible reasons for the variation in the gender descriptions of the five dictionaries and their different editions. Changes in the real world have caused some of the gender assignments to become outdated. The breaking down of gender boundaries in working life and sports has no doubt had an influence on the drafting of the entries for words such as priest, boxer, soldier, 
and stripper. One is hardly likely to see priest defined as a clergyman, or boxer as a sportsman, in modern dictionaries. As regards the presentation of the terminology for clothes, unisex fashion may have contributed to the loss of gender comments in areas such as underwear terminology.

Variation in the size and content of the corpora used by lexicographers is another factor likely to underlie some of the differences between the gender descriptions found in the five works studied. The omission of gender information may at first seem puzzling in cases such as bastard in $C A L D$, described as "an extremely unpleasant person, esp. a man” in the first (1995) edition, later on as “an unpleasant person”. The male association of the word was apparently still strong in the 1980s, when Frank and Anshen stated that "[i]f someone is called a bastard, either as a general term of abuse, or as a statement of the lack of legal marital ties between that person's parents, we assume that person is a male". ${ }^{55}$ A decade later, Hughes characterized the word as being “invariably applied only to males”. ${ }^{56}$ Such categorical statements are, however, contradicted by evidence from the Lancaster Corpus of Abuse (LCA), where the targets of the slur may be of either sex. The compilers of the corpus observe that gender exclusive terms of abuse are "the exception rather than the norm" in their data. ${ }^{57}$ The number of female referents of bastard in corpora of informal English is, nevertheless, still a far cry from the male occurrences, ${ }^{58}$ which questions the policy of omitting any

\footnotetext{
${ }^{55}$ Frank and Anshen, 66.

${ }^{56}$ Hughes, 208.

${ }^{57}$ McEnery et al., 52.

${ }^{58}$ The search strings "she is a bastard", "she’s a bastard", "she is a * bastard”, and "she’s a * bastard" yield only one hit in the Corpus of Global Web-Based English created by Davies. The
} 
mention of gender in the dictionary entry.

As concerns the role of corpora, it should be noted that the OALD and $L D O C E$ editions that were published before the late 1980s did not rely on electronic corpora. The variation in the gender comments of earlier times, seen for example in the treatment of bastard and hero, has more to do with the compilers' personal opinions about the usage of the word.

Discussions about gender-biassed language and stereotyped images of men and women have probably also had an effect on the wording of some of the definitions studied for the present article. There are words and phrases that in corpora occur primarily in contexts associated with one of the sexes. Such uses can sometimes be considered pejorative or sexist. The lexicographer's dilemma then is to decide whether the gender association should be mentioned in the dictionary entry or omitted because of the danger of reinforcing stereotypes. Whitcut argues that "what we are describing as lexicographers is language itself, and it is our business to describe the language as it is”, which is why "[i]f all the citational evidence suggests that the verb nag is generally used with a female subject, [she] ought to say so". ${ }^{59}$ Rundell agrees that the basic task of a lexicographer is to explain the meanings of words by observing their actual use. Any gender bias should, however, be avoided, wherefore the importance of portraying women in positive roles in definitions and example sentences. Rundell also mentions

corresponding search strings with he reveal 90 occurrences. None of the 41 hits for "what a bastard" refers to women.

${ }^{59}$ Whitcut, 142. 
the particular importance in learner's dictionaries of supplying offensive words with warnings about the effects that they may produce in the listener or reader. ${ }^{60}$

Of the twenty-five words studied, hero has been extensively commented upon in debates about gender-biassed language. Since the 1970 s, ${ }^{61}$ there have been calls to treat hero as a gender-neutral word, the separate terms hero and heroine being seen as perpetuating gender stereotypes and making women seem non-standard. The male emphasis in the concept of what it means to be a hero has also been criticized. ${ }^{62}$ The entries for hero in the five learner's dictionaries vary as regards mentions of gender. $C A L D$ and $M E D A L$ consider hero in the bravery sense a gender-neutral word, in contrast to the three other works, which state that the referent is "a man" or "especially a man”. It is possible that the main reason for the differences in the descriptions is not the corpus evidence available to each dictionary, but the lexicographers' varied responses to calls for extending the scope of the word to cover women as well. That the compilers of the learner's dictionaries examined are aware of the debates surrounding sexist language is certainly shown by the omission of earlier references to "qualities considered as male”, “qualities believed to be typical of men or boys”, and "qualities thought to be typical of boys, eg courage and a sense of adventure” in the entries for sissy in $C A L D, L D O C E$, and $O A L D$, respectively.

\footnotetext{
${ }^{60}$ Rundell, “A Nice Girl like you.”

${ }^{61}$ Cameron notes that it was the early 1970s that saw the emergence of "serious feminist criticism of mainstream/malestream dictionaries”.

${ }^{62}$ Doyle, 38; Fayer, 27; Golden, 43; Kramarae et al., 189; Miller and Swift, Handbook, 139-41.
} 
Some of the changes from one edition of the dictionary to the next do not seem explicable by changes in the real world, corpus evidence, or discussions about nonbiassed vocabulary. It is difficult to see any of those factors behind the decision to remove the mention of men from the entries for fez and sombrero in some of the dictionaries. Rather, it would appear that here the lexicographers have assessed the importance of the gender component of meaning differently. For some of them, the description of the physical appearance of the object is enough, with no need to add information about the sex of the wearer. The language learner's view of the matter may well be different. If a word is predominantly applied to one of the sexes, most learners would probably appreciate knowing that, because the information might help them to avoid producing a sentence that sounds unidiomatic or somehow "not right”. In some instances, the omission of any comment on gender may in fact affect the mental image of the referent. Some learner's dictionaries define swimsuit as "a piece of clothing for swimming”, others adding that the garment so called is worn especially by women or girls. The genderless definition would equally cover monokinis, bikinis, and swimming trunks, the focus in the gendered version being on the two first-mentioned types of swimwear.

In a dictionary intended for learners, definitions should be drafted in such a way as to enable the learner to use the words in a natural manner in a foreign-language environment. The learner's own culture may be very different from that environment, and it is therefore important to include cultural information, and information about the associations of a word, where such explanations are relevant for the idiomatic use of the word. Comments about gender need to be non-biassed, yet informative about the contexts where the word is typically found. Uses generally perceived as offensive should be labelled as such or furnished with a usage note. The analysis of the definitions 
of the example words in the five learner's dictionaries shows that gender is not an easy matter to handle in lexicography. Rundell's description of issues of language and gender as a "minefield" 63 is appropriate indeed.

References

Learner's dictionaries

CALD:

Procter, Paul, et al., eds. Cambridge International Dictionary of English. Cambridge: Cambridge University Press, 1995.

Walter, Elizabeth, et al., eds. Cambridge Advanced Learner's Dictionary. 2d-4th eds. Cambridge: Cambridge University Press, 2005, 2008, 2013.

https://dictionary.cambridge.org (accessed August 22, 2018).

Cobuild:

Sinclair, John, et al., eds. Collins COBUILD Advanced Learner's Dictionary. 9 eds. Glasgow: HarperCollins, 1987, 1995, 2001, 2003, 2006, 2014, 2018. Boston: Heinle Cengage Learning, 2009, 2012.

https://www.collinsdictionary.com/dictionary/english (accessed August 22, 2018).

LDOCE:

${ }^{63}$ Rundell, “A Nice Girl like you.” 
Procter, Paul, et al., eds. Longman Dictionary of Contemporary English. 6 eds. Harlow, Essex: Longman, 1978, 1987, 1995. Harlow, Essex: Pearson Education Limited, 2003, 2009, 2014.

https://www.ldoceonline.com (accessed August 22, 2018).

MEDAL:

Rundell, Michael, et al., eds. Macmillan English Dictionary for Advanced Learners. 2 eds. Oxford: Macmillan Education, 2002, 2007.

https://www.macmillandictionary.com (accessed August 22, 2018)

$O A L D:$

Hornby, Albert Sidney, Edward Vivian Gatenby, and Harold Wakefield. A Learner's Dictionary of Current English. London: Oxford University Press, 1948.

—. The Advanced Learner's Dictionary of Current English. 2d ed. London: Oxford University Press, 1963.

Hornby, Albert Sidney, Anthony Paul Cowie, and J. Windsor Lewis. Oxford Advanced Learner's Dictionary of Current English. 3d ed. Oxford: Oxford University Press, 1974.

Cowie, Anthony Paul, et al., eds. Oxford Advanced Learner's Dictionary of Current English. 4th-9th eds. Oxford: Oxford University Press, 1989, 1995, 2000, 2005, 2010, 2015.

https://www.oxfordlearnersdictionaries.com (accessed August 22, 2018).

Other references

Astle, David. “Shrill Voice of Oxford Dictionary Shows Grating Gender Bias.” The Sydney Morning Herald, March 29, 2016. https://www.smh.com.au/entertainment/books/shrill-voice-of-oxford-dictionaryshows-grating-gender-bias-20160328-gns7m9.html (accessed January 30, 2019).

Atkins, B. T. Sue, and Michael Rundell. The Oxford Guide to Practical Lexicography. Oxford: Oxford University Press, 2008. 
Ayto, John R. “On Specifying Meaning: Semantic Analysis and Dictionary

Definitions.” In Lexicography: Principles and Practice, edited by Reinhard R.

K. Hartmann, 89-98. London: Academic Press, 1983.

Baron, Dennis. Grammar and Gender. New Haven/London: Yale University Press, 1986.

Bauer, Laurie. Watching English Change: An Introduction to the Study of Linguistic Change in Standard Englishes in the Twentieth Century. London/New York: Longman, 1994.

Bauer, Laurie, Rochelle Lieber, and Ingo Plag. The Oxford Reference Guide to English Morphology. Oxford: Oxford University Press, 2013.

Beardsley, Elizabeth Lane. “Degenderization.” In Sexist Language: A Modern Philosophical Analysis, edited by Mary Vetterling-Braggin, 155-60. Littlefield: Adams and Co., 1981.

Béjoint, Henri. The Lexicography of English: From Origins to Present. Oxford: Oxford University Press, 2010.

Benson, Morton, Evelyn Benson, and Robert Ilson. Lexicographic Description of English. Amsterdam/Philadelphia: Benjamins, 1986.

Bogaards, Paul. “Dictionaries for Learners of English.” International Journal of Lexicography 9, no. 4 (1996): 277-320.

Brewer, Charlotte. “The 'Electronification’ of the Oxford English Dictionary.” Dictionaries 25 (2004): 1-43.

Burchfield, Robert William, ed. The New Fowler's Modern English Usage. 3d ed. Oxford: Clarendon Press, 1996.

Burridge, Kate. Blooming English: Observations on the Roots, Cultivation and Hybrids of the English Language. Cambridge: Cambridge University Press, 2004.

- Weeds in the Garden of Words: Further Observations on the Tangled History of the English Language. Cambridge: Cambridge University Press, 2005.

Cameron, Deborah. “Dictionaries, Dick-tionaries and Dyketionaries.” Language: A Feminist Guide, June 30, 2015. https://debuk.wordpress.com/2015/06/30/dictionaries-dick-tionaries-anddyketionaries/ (accessed February 2, 2019).

Caplan-Bricker, Nora. “Should Dictionaries do More to Confront Sexism?” The New Yorker, February 23, 2016. https://www.newyorker.com/books/page- 
turner/should-dictionaries-do-more-to-confront-sexism (accessed January 30, 2019).

Carter, Ronald. Vocabulary: Applied Linguistic Perspectives. 2d ed. London/New York: Routledge, 2012.

Coleman, Julie. “Slang Used by Students at the University of Leicester (2004-11).” In Global English Slang: Methodologies and Perspectives, edited by Julie Coleman, 49-61. London/New York: Routledge, 2014.

Cowie, Anthony Paul. English Dictionaries for Foreign Learners: A History. Oxford: Oxford University Press, 1999.

—. “The Learner's Dictionary in a Changing Cultural Perspective.” In Cultures, Ideologies, and the Dictionary: Studies in Honor of Ladislav Zgusta, edited by Braj J. Kachru and Henry Kahane, 283-95. Tübingen: Niemeyer, 1995.

Crum, Maddie. “It’s 2016, and Even the Dictionary is Full of Sexist Disses.” The Huffington Post, August 30, 2016. https://www.huffingtonpost.com/entry/sexistdictionary-definitions_us_57c59757e4b0cdfc5ac93cd6 (accessed January 30, 2019).

Davies, Mark. Corpus of Global Web-Based English: 1.9 Billion Words from Speakers in 20 Countries (GloWbE). https://corpus.byu.edu/glowbe/. 2013.

Dovey, Hugh. “French Dressing.” Modern Languages 68, no. 3 (1987): 169-72.

Doyle, Margaret. The A-Z of Non-Sexist Language. London: Women’s Press, 1995.

Eckert, Penelope, and Sally McConnell-Ginet. Language and Gender. 2d ed. Cambridge: Cambridge University Press, 2013.

England, Charlotte. “Woman Persuades Dictionary to Change Definition of Femininity.” The Independent, November 17, 2016. https://www.independent.co.uk/news/world/americas/femininity-definitiondictionary-woman-persuades-merriam-webster-to-change-sexism-usagea7422426.html (accessed January 30, 2019).

Fayer, Joan. “Are Heroes Always Men?” In American Heroes in a Media Age, edited by Susan J. Drucker and Robert S. Cathcart, 24-35. Cresskill, NJ: Hampton Press, 1994.

Ferrier, Morwenna. “Why Women are Buying Men’s Underwear.” The Guardian, October 29, 2014. https://www.theguardian.com/fashion/2014/oct/29/is-this-theend-of-gender-specific-underwear-or-just-a-load-of-pants (accessed September 26, 2018). 
Flood, Alison. "Sexism Row Prompts Oxford Dictionaries to Review Language Used in Definitions.” The Guardian, January 25, 2016. https://www.theguardian.com/books/2016/jan/25/oxford-dictionary-reviewsexist-language-rabid-feminist-gender (accessed January 30, 2019).

Foster, Brian. The Changing English Language. Harmondsworth: Penguin, 1970.

Frank, Francine, and Frank Anshen. Language and the Sexes. Albany: State University of New York Press, 1983.

Gershuny, H. Lee. "Sexism in Dictionaries and Texts: Omissions and Commissions.” In Sexism and Language, edited by Alleen Pace Nilsen, Haig Bosmajian, H. Lee Gershuny, and Julia P. Stanley, 143-59. Urbana: National Council of Teachers of English, 1977.

Gold, David. Review of Benson, Morton, Evelyn Benson, and Robert Ilson. The BBI Combinatory Dictionary of English: A Guide to Word Combinations. Amsterdam/Philadelphia: John Benjamins, 1986. International Journal of Lexicography 1, no. 1 (1988): 56-59.

Golden, Jill. "Heroes and Gender: Children Reading and Writing.” English in Australia, no. 110 (1994), 42-52.

Green, Jonathon. Cassell's Dictionary of Slang. 2d ed. London: Weidenfeld \& Nicolson, 2005.

Hanks, Patrick, and Flavia Hodges. A Dictionary of First Names. Oxford: Oxford University Press, 1990.

Hanks, Patrick, Kate Hardcastle, and Flavia Hodges. A Dictionary of First Names. 2d ed. Oxford: Oxford University Press, 2006.

Hellinger, Marlis, and Anne Pauwels. “Language and Sexism.” In Handbook of Language and Communication: Diversity and Change, edited by Marlis Hellinger and Anne Pauwels, 651-84. Berlin: Mouton de Gruyter, 2007.

Herbst, Thomas. “On the Way to the Perfect Learners’ Dictionary: A First Comparison of OALD5, LDOCE3, COBUILD2 and CIDE.” International Journal of Lexicography 9, no. 4 (1996): 321-57.

Hughes, Geoffrey. Swearing: A Social History of Foul Language, Oaths and Profanity in English. Harmondsworth: Penguin, 1998.

Jackson, Howard. Lexicography: An Introduction. London: Routledge, 2002.

Kaye, Patricia. “'Women are Alcoholics and Drug Addicts’, says Dictionary.” ELT Journal 43, no. 3 (1989): 192-5. 
Kestler-d'Amours, Jillian. “Oxford Dictionaries in Hot Water over 'Rabid Feminist' Example.” The Star, January 26, 2016.

https://www.thestar.com/news/canada/2016/01/26/oxford-dictionaries-in-hotwater-over-rabid-feminist-example.html (accessed January 30, 2019).

Kramarae, Cheris, Paula A. Treichler, and Ann Russo. Amazons, Bluestockings and Crones: A Feminist Dictionary. 2d ed. London: Pandora Press, 1992.

Landau, Sidney I. Dictionaries: The Art and Craft of Lexicography. 2d ed. Cambridge: Cambridge University Press, 2001.

—. "The Expression of Changing Social Values in Dictionaries.” Dictionaries 7 (1985): 261-9.

Lawson, Sarah. “Guy and Guys.” American Speech 57, no. 2 (1982): 157-8.

Lederer, Richard. “A Quiz about Sexist Language.” Verbatim 11, no. 1 (1984): 14-15.

Lehrer, Adrienne. “The Influence of Semantic Fields on Semantic Change.” In

Historical Semantics - Historical Word-Formation, edited by Jacek Fisiak, 28396. Berlin: Mouton, 1985.

McEnery, Anthony, John Paul Baker, and Andrew Hardie. “Assessing Claims about Language Use with Corpus Data - Swearing and Abuse.” In Corpora Galore: Analyses and Techniques in Describing English, edited by John M. Kirk, 45-55. Amsterdam: Rodopi, 2000.

Miller, Casey, and Kate Swift. The Handbook of Nonsexist Writing. 2d ed. Lincoln, NE: iUniverse, 2001.

—. Words and Women: New Language in New Times. New York: Doubleday, 1976.

Norri, Juhani. “Gender-Referential Shifts in English.” English Studies 79, no. 3 (1998): 270-87.

—. "Labelling of Derogatory Words in Some British and American Dictionaries." International Journal of Lexicography 13, no. 2 (2000): 71-106.

—. "Lexical Gender-Benders in Underwear.” In Voicing Gender, edited by Yvonne Hyrynen, 63-101. Tampere: University of Tampere, 1996.

Nunberg, Geoffrey. "What the Usage Panel Thinks.” In The State of the Language, edited by Christopher Ricks and Leonard Michaels, 467-82. Berkeley/Los Angeles: University of California Press, 1990.

Pauwels, Anne. Women Changing Language. London: Longman, 1998. 
Rawson, Hugh. Wicked Words: A Treasury of Curses, Insults, Put-Downs, and Other Formerly Unprintable Terms from Anglo-Saxon Times to the Present. New York: Crown, 1989.

Rundell, Michael. "Stop the Presses - The End of the Printed Dictionary.” Macmillan Dictionary Blog, 2012. http://www.macmillandictionaryblog.com/bye-printdictionary (accessed August 27, 2018).

—. "What's a Nice Girl like you Doing in a Dictionary like this?” Macmillan Dictionary Blog, 2012. http://www.macmillandictionaryblog.com/whats-a-nicegirl-like-you-doing-in-a-dictionary-like-this (accessed January 30, 2019).

Schulz, Muriel R. “The Semantic Derogation of Woman.” In Language and Sex: Difference and Dominance, edited by Barrie Thorne and Nancy Henley, 64-75. Rowley, Mass.: Newbury House, 1975.

Sciarretto, Amy. "Les Girls Les Boys is the Unisex Underwear Brand You Need on Your Radar.” Bustle, May 4, 2017. https://www.bustle.com/p/les-girls-les-boysis-the-unisex-underwear-brand-you-need-on-your-radar-55647 (accessed September 26, 2018).

Simpson, John, Michael Proffitt, et al., eds. The Oxford English Dictionary. 3d ed. online. Oxford: Oxford University Press, 2000-. http://www.oed.com (accessed September 9th, 2018).

Snodgrass, Mary Ellen. World Clothing and Fashion: An Encyclopedia of History, Culture, and Social Influence. London/NewYork: Routledge, 2015.

Svensén, Bo. A Handbook of Lexicography: The Theory and Practice of DictionaryMaking. Cambridge: Cambridge University Press, 2009.

Waksler, Rachelle. "She’s a Mensch and he’s a Bitch: Neutralizing Gender in the 90s.” English Today 11, no. 2 (1995): 3-6.

Whitcut, Janet. “Sexism in Dictionaries.” In LEXeter '83 Proceedings, edited by Reinhard R. K. Hartmann, 141-4. Tübingen: Niemeyer, 1984.

Withycombe, Elizabeth Gidley. The Oxford Dictionary of English Christian Names. 3d ed. Oxford: Oxford University Press, 1977.

Yamada, Shigeru. “Monolingual Learners’ Dictionaries - Where Now?” In The Bloomsbury Companion to Lexicography, edited by Howard Jackson, 188-212. London: Bloomsbury, 2013. 
Table 1 Gender specifications for bastard 'an unpleasant person' / 'a person of the stated kind'.

\begin{tabular}{|c|c|c|c|c|c|}
\hline date & $O A L D$ & Cobuild & LDOCE & CALD & $M E D A L$ \\
\hline 1948 & $\begin{array}{l}\text { neither } \\
\text { meaning } \\
\text { given }\end{array}$ & & & & \\
\hline 1963 & $\begin{array}{l}\text { neither } \\
\text { meaning } \\
\text { given }\end{array}$ & & & & \\
\hline 1974 & $\begin{array}{l}\text { unspecified / } \\
\text { man }\end{array}$ & & & & \\
\hline 1978 & & & man / man & & \\
\hline 1987-9 & $\begin{array}{l}\text { man (usu.) / } \\
\text { man (usu.) }\end{array}$ & $\begin{array}{l}\text { unspecified / } \\
\text { unspecified }\end{array}$ & $\begin{array}{l}\text { unspecified / } \\
\text { man (esp.) }\end{array}$ & & \\
\hline 1995 & $\begin{array}{l}\text { man (usu.) / } \\
\text { man (esp.) }\end{array}$ & $\begin{array}{l}\text { man (usu.) / } \\
\text { man (usu.) }\end{array}$ & $\begin{array}{l}\text { man (esp.) / } \\
\text { man }\end{array}$ & $\begin{array}{l}\text { man (esp.) / } \\
\text { man (esp.) }\end{array}$ & \\
\hline 2000-1 & $\begin{array}{l}\text { man (esp.) / } \\
\text { man (esp.) }\end{array}$ & $\begin{array}{l}\text { man (esp.) / } \\
\text { man (usu.) }\end{array}$ & & & \\
\hline $2002-3$ & & $\begin{array}{l}\text { man (esp.) / } \\
\text { meaning not } \\
\text { given }\end{array}$ & $\begin{array}{l}\text { man (esp.) / } \\
\text { man }\end{array}$ & & $\begin{array}{l}\text { man / } \\
\text { unspecified }\end{array}$ \\
\hline $2005-7$ & $\begin{array}{l}\text { man (esp.) / } \\
\text { man (esp.) }\end{array}$ & $\begin{array}{l}\text { man (esp.) / } \\
\text { meaning not } \\
\text { given }\end{array}$ & & $\begin{array}{l}\text { unspecified / } \\
\text { unspecified }\end{array}$ & $\begin{array}{l}\text { man / } \\
\text { unspecified }\end{array}$ \\
\hline
\end{tabular}




\begin{tabular}{|c|c|c|c|c|c|}
\hline $2008-10$ & $\begin{array}{l}\text { man (esp.) / } \\
\text { man (esp.) }\end{array}$ & $\begin{array}{l}\text { man (esp.) / } \\
\text { meaning not } \\
\text { given }\end{array}$ & $\begin{array}{l}\text { man (esp.) / } \\
\text { man }\end{array}$ & $\begin{array}{l}\text { unspecified / } \\
\text { unspecified }\end{array}$ & \\
\hline 2012 & & $\begin{array}{l}\text { man (esp.) / } \\
\text { meaning not } \\
\text { given }\end{array}$ & & & \\
\hline $2013-5$ & $\begin{array}{l}\text { man (esp.) / } \\
\text { man (esp.) }\end{array}$ & $\begin{array}{l}\text { man (esp.) / } \\
\text { meaning not } \\
\text { given }\end{array}$ & $\begin{array}{l}\text { man (esp.) / } \\
\text { man }\end{array}$ & $\begin{array}{l}\text { unspecified / } \\
\text { unspecified }\end{array}$ & \\
\hline 2018 & & $\begin{array}{l}\text { man (esp.) / } \\
\text { meaning not } \\
\text { given }\end{array}$ & & & \\
\hline online & $\begin{array}{l}\text { man (esp.) / } \\
\text { man (esp.) }\end{array}$ & $\begin{array}{l}\text { man (esp.) / } \\
\text { man (usu.) }\end{array}$ & $\begin{array}{l}\text { man (esp.) / } \\
\text { man }\end{array}$ & $\begin{array}{l}\text { unspecified / } \\
\text { unspecified }\end{array}$ & $\begin{array}{l}\text { man / } \\
\text { unspecified }\end{array}$ \\
\hline
\end{tabular}

Table 2 Gender specifications for hero 'person famous for bravery' / 'main character in a story'.

\begin{tabular}{|c|l|l|l|l|l|}
\hline date & OALD & Cobuild & LDOCE & CALD & MEDAL \\
\hline 1948 & boy or man & & & & \\
& $/$ man & & & & \\
\hline 1963 & boy or man & & & & \\
& $/$ man & & & & \\
\hline
\end{tabular}




\begin{tabular}{|c|c|c|c|c|c|}
\hline 1974 & $\begin{array}{l}\text { unspecified } \\
\text { / unspecified }\end{array}$ & & & & \\
\hline 1978 & & & $\begin{array}{l}\text { unspecified } \\
\text { / man }\end{array}$ & & \\
\hline 1987-9 & $\begin{array}{l}\text { unspecified } \\
\text { / man }\end{array}$ & $\begin{array}{l}\text { unspecified } \\
\text { / man }\end{array}$ & $\begin{array}{l}\text { unspecified } \\
\text { / } \\
\text { unspecified }\end{array}$ & & \\
\hline 1995 & $\begin{array}{l}\text { unspecified } \\
\text { / man }\end{array}$ & $\begin{array}{l}\text { man (esp.) / } \\
\text { man }\end{array}$ & $\begin{array}{l}\text { man / man } \\
\text { or boy }\end{array}$ & $\begin{array}{l}\text { unspecified } \\
\text { / } \\
\text { unspecified }\end{array}$ & \\
\hline $2000-1$ & $\begin{array}{l}\operatorname{man} \text { (esp.) / } \\
\text { man }\end{array}$ & $\begin{array}{l}\text { man (esp.) / } \\
\text { man }\end{array}$ & & & \\
\hline $2002-3$ & & $\begin{array}{l}\text { man (esp.) / } \\
\text { man }\end{array}$ & $\begin{array}{l}\text { man / man } \\
\text { or boy }\end{array}$ & & $\begin{array}{l}\text { unspecified } \\
\text { / man }\end{array}$ \\
\hline $2005-7$ & $\begin{array}{l}\operatorname{man}(\text { esp.) / } \\
\text { man }\end{array}$ & $\begin{array}{l}\text { man (esp.) / } \\
\text { man }\end{array}$ & & $\begin{array}{l}\text { unspecified } \\
\text { / man }\end{array}$ & $\begin{array}{l}\text { unspecified } \\
\text { / man }\end{array}$ \\
\hline 2008-10 & $\begin{array}{l}\operatorname{man} \text { (esp.) / } \\
\text { man }\end{array}$ & $\begin{array}{l}\text { man (esp.) / } \\
\text { man }\end{array}$ & $\begin{array}{l}\text { man / man } \\
\text { or boy }\end{array}$ & $\begin{array}{l}\text { unspecified } \\
\text { / man }\end{array}$ & \\
\hline 2012 & & $\begin{array}{l}\text { man (esp.) / } \\
\text { man }\end{array}$ & & & \\
\hline $2013-5$ & $\begin{array}{l}\text { man (esp.) / } \\
\text { man }\end{array}$ & $\begin{array}{l}\text { man (esp.) / } \\
\text { man }\end{array}$ & $\begin{array}{l}\text { man / man } \\
\text { or boy }\end{array}$ & $\begin{array}{l}\text { unspecified } \\
\text { / man }\end{array}$ & \\
\hline 2018 & & $\begin{array}{l}\text { man (esp.) / } \\
\text { man }\end{array}$ & & & \\
\hline
\end{tabular}




\begin{tabular}{|c|l|l|l|l|l|}
\hline online & man (esp.) / & man (esp.) / & man / man & unspecified & unspecified \\
& man & man & or boy & $/$ man & $/$ man \\
\hline
\end{tabular}

